\title{
Anti-HIV-I nanotherapeutics: promises and challenges for the future
}

This article was published in the following Dove Press journal:

International Journal of Nanomedicine

4 October 2012

Number of times this article has been viewed

\author{
Supriya D Mahajan' \\ Ravikumar Aalinkeel' \\ Wing-Cheung Law ${ }^{2}$ \\ Jessica L Reynolds' \\ Bindukumar B Nair' \\ Donald E Sykes' \\ Ken-Tye Yong ${ }^{4}$ \\ Indrajit Roy ${ }^{3}$ \\ Paras N Prasad ${ }^{2}$ \\ Stanley A Schwartz' \\ 'Department of Medicine, Division \\ of Allergy, Immunology, and \\ Rheumatology, ${ }^{2}$ Institute for Lasers \\ Photonics and Biophotonics, State \\ University of New York at Buffalo, \\ Buffalo Niagara Medical Campus, \\ Buffalo, NY, USA; ${ }^{3}$ Department of \\ Chemistry, University of Delhi, \\ Delhi, India; ${ }^{4}$ School of Electrical \\ and Electronic Engineering, Nanyang \\ Technological University, Singapore, \\ Singapore
}

Correspondence: Supriya D Mahajan Research Assistant Professor, Department of Medicine, Division of Allergy, Immunology, and Rheumatology, 444 Innovation Center, Buffalo Niagara Medical Campus, 640 Ellicott Street, Buffalo, NY 14203, USA

Tel +17162187962

Fax +I 7162187385

Email smahajan@buffalo.edu
Abstract: The advent of highly active antiretroviral therapy (HAART) has significantly improved the prognosis for human immunodeficiency virus (HIV)-infected patients, however the adverse side effects associated with prolonged HAART therapy use continue. Although systemic viral load can be undetectable, the virus remains sequestered in anatomically privileged sites within the body. Nanotechnology-based delivery systems are being developed to target the virus within different tissue compartments and are being evaluated for their safety and efficacy. The current review outlines the various nanomaterials that are becoming increasingly used in biomedical applications by virtue of their robustness, safety, multimodality, and multifunctionality. Nanotechnology can revolutionize the field of HIV medicine by not only improving diagnosis, but also by improving delivery of antiretrovirals to targeted regions in the body and by significantly enhancing the efficacy of the currently available antiretroviral medications.

Keywords: nanotherapeutics, HAART, HIV, nano, nanomedicine, drug delivery

\section{Introduction}

Human immunodeficiency virus (HIV)/acquired immunodeficiency syndrome (AIDS) is a global pandemic and is the leading infectious disease resulting in significant morbidity and mortality and consequently devastating socioeconomic effects. With the advent of multidrug, highly active antiretroviral therapy (HAART), the prognosis for HIV-infected patients has significantly improved; however, it has not eradicated HIV infection, particularly in sequestered, anatomically privileged sites, such as the brain, testes, gut, liver, kidney, and secondary lymphoid tissue. Additionally, emergence of resistant viral strains and the adverse side effects associated with prolonged use continue to slow down the application of effective antiviral therapies. Nanotechnology is an emerging multidisciplinary field that has the potential to advance the treatment and prevention of HIV/AIDS radically. The use of nanotechnology for numerous biomedical applications has become an area of intense research over the last decade. ${ }^{1-10}$

The potential advantages of using nanomedicine over conventional HIV therapies include the capacity to incorporate, encapsulate, or conjugate a variety of drugs to target specific cell populations and to offer tunable and site-specific drug release. ${ }^{11-20}$ Table 1 outlines the different types of current nanotherapeutics in HIV and lists their advantages and limitations. Although HIV-1 nanotherapeutics have the potential to address key issues of traditional HIV-1 therapy, such as overcoming cellular 
Table I Types of nanotherapy in HIV

\begin{tabular}{|c|c|c|}
\hline Nanotherapeutics in HIV & Advantages & Limitations \\
\hline $\begin{array}{l}\text { Nanotechnology-based delivery of } \\
\text { antiretroviral therapy } \\
\text { - Improves stability and allows sustained release } \\
\text { of the antiretroviral drug } \\
\text { - Allows efficient crossing of the drug across } \\
\text { cellular barriers or the ability to traverse the } \\
\text { epithelial/endothelial barriers such as the BBB }\end{array}$ & $\begin{array}{l}\text { - Intracellular drug concentrations are higher } \\
\text { with encapsulated antiretroviral compared with } \\
\text { free drug solution } \\
\text { - Increased permeability of these drugs across } \\
\text { the cellular membranes } \\
\text { - Improved bioavailability and increased cellular } \\
\text { uptake } \\
\text { - Sustained release } \\
\text { - Reduction of immunogenic response }\end{array}$ & $\begin{array}{l}\text { - May be too large for renal clearance } \\
\text { - Unpredictable intracellular effects } \\
\text { - Nanoparticles not easily degraded or } \\
\text { metabolized and may accumulate over } \\
\text { a period of time }\end{array}$ \\
\hline $\begin{array}{l}\text { Nanotherapy using nanoparticles as } \\
\text { therapeutic agents } \\
\text { - Anti-HIV-I effects of inorganic nanoparticles } \\
\text { (gold/silver) alone } \\
\text { - Targeting the RES allows opsonization } \\
\text { (ie, aggregation of nanoparticles in the RES) } \\
\text { resulting in activation of the immune system } \\
\text { via phagocytic mechanisms and clearance of } \\
\text { nanoparticles from systemic circulation and } \\
\text { accumulation in the RES where HIV persists }\end{array}$ & $\begin{array}{l}\text { - Gold/silver have antiviral properties against a } \\
\text { wide range of HIV-I strains } \\
\text { - Act as viral entry inhibitors } \\
\text { - Inhibit post-entry stages of HIV-I } \\
\text { - Reduced risk of viral resistance to these } \\
\text { nanoparticles } \\
\text { - Surface modification of nanoparticles can } \\
\text { improve cytotoxicity. Safe and effective }\end{array}$ & $\begin{array}{l}\text { - High toxicity issues result in DNA } \\
\text { damage and cellular apoptosis } \\
\text { - No data on metabolic effects of } \\
\text { nanoparticles }\end{array}$ \\
\hline $\begin{array}{l}\text { HIV gene therapy: RNA- and DNA-based } \\
\text { therapies } \\
\text { - Antisense RNAs, RNA aptamers, RNA decoys, } \\
\text { and siRNA therapeutics to HIV-I-specific cells }\end{array}$ & $\begin{array}{l}\text { - Nonviral, safe, and effective delivery of } \\
\text { siRNA/antisense to target cells } \\
\text { - Controlled release, improved stability } \\
\text { in physiological milieu, and protection } \\
\text { from degradation }\end{array}$ & $\begin{array}{l}\text { Preclinical trials show promise. } \\
\text { However, there are major scale-up } \\
\text { limitations }\end{array}$ \\
\hline $\begin{array}{l}\text { Nanotechnology-based immunotherapy } \\
\text { for HIV } \\
\text { - Targets immune response against HIV using } \\
\text { immunomodulatory agents such as delivery } \\
\text { of cytokines/dendritic cells (DCs) for antigen } \\
\text { presentation } \\
\text { - In vivo targeting of DCs and delivery of } \\
\text { small molecules and proteins that have } \\
\text { immunotherapeutic potential } \\
\text { - HIV vaccine delivery }\end{array}$ & $\begin{array}{l}\text { - Potential as adjuvants and delivery system for } \\
\text { vaccines } \\
\text { - Release antigen in a controlled manner leading } \\
\text { to strong and sustained immune response } \\
\text { - Increases half-life of the immunogen } \\
\text { - Can be optimized for various routes of } \\
\text { administration }\end{array}$ & $\begin{array}{l}\text { - Nanoparticles induce strong humoral } \\
\text { and cellular immunity, the mechanisms } \\
\text { of which are as yet undefined }\end{array}$ \\
\hline $\begin{array}{l}\text { Prevent viral transmission } \\
\text { - Intravaginal microbicides that target the virus } \\
\text { or inhibit viral entry by preventing viral binding } \\
\text { to target cells }\end{array}$ & $\begin{array}{l}\text { - Biodegradable nanoparticles are effective } \\
\text { delivery vehicles of microbicides to vaginal } \\
\text { mucosa } \\
\text { - Some epithelial penetration capability }\end{array}$ & $\begin{array}{l}\text { - Enhance tissue penetration needed } \\
\text { - Penetration and residence time of the } \\
\text { nanoparticles in the mucus depends } \\
\text { on mucus and physiologic conditions }\end{array}$ \\
\hline $\begin{array}{l}\text { Targeting latent reservoirs } \\
\text { - Targeting HIV, which is sequestered in sanctuary } \\
\text { sites such as brain, testes, secondary lymphoid } \\
\text { tissue }\end{array}$ & $\begin{array}{l}\text { - Nanoparticles traverse BBB by endocytosis/ } \\
\text { phagocytosis and can then release drug } \\
\text { intracellularly }\end{array}$ & $\begin{array}{l}\text { - To achieve optimal concentration of } \\
\text { antiretroviral in cells of the central } \\
\text { nervous system that harbors the virus }\end{array}$ \\
\hline
\end{tabular}

Abbreviations: BBB, blood-brain barrier; DC, dendritic cell; HIV, human immunodeficiency virus; RES, reticuloendothelial system; siRNA, small interfering RNA.

and anatomical barriers, drug toxicity, drug resistance, suboptimal adherence, and virus sequestration, a number of obstacles remain which include safety and efficacy profiles and long-term toxicity, unwarranted immune response, and scale-up and cost considerations of large scale synthesis of these nanoparticle platforms. ${ }^{21-29}$

\section{Types of nanomaterials}

A wide range of nanomaterials have been used in biomedicine, these encompass dendrimers, liposomes, micelles, nanoemulsions, nanocapsules, nanocrystals, nanotubes, and nanoparticles. ${ }^{30-45}$ Table 2 lists the commonly used nanomaterials in biomedical applications. The current review focuses predominantly on nanoparticles used in HIV-1 therapeutics. Nanoparticles are solid colloidal particles typically in the size range of 10-1000 nm, in which therapeutic agents either alone or in combination can be entrapped or chemically linked to the surface. Nanoparticles offer more stability to encapsulated drugs in biological fluids and also protect the encapsulated drugs against enzymatic degradation. ${ }^{46}$ Due to their small size they can be taken up by cells where the uptake of larger particles is precluded. 
Table 2 Types of nanomaterials

\begin{tabular}{|c|c|c|}
\hline Types of nanomaterials used in HIV therapeutics & Advantages & Limitations \\
\hline $\begin{array}{l}\text { Liposomes } \\
\text { Lipid vesicles consisting of phospholipid bilayers with } \\
\text { an aqueous core which can be used to encapsulate } \\
\text { hydrophilic drugs while hydrophobic and amphiphilic } \\
\text { drugs can be solubilized within the phospholipid } \\
\text { bilayers } \\
\text { Dendrimers } \\
\text { Dendrimers have a branched three-dimensional } \\
\text { architecture and are synthesized by attaching several } \\
\text { monomeric units and have minimal polydispersity and } \\
\text { high functionality. Characterized by a polyfunctional } \\
\text { core that can encapsulate several chemical moieties, } \\
\text { interior layers, and multivalent surface }\end{array}$ & $\begin{array}{l}\text { - Quick clearance from circulation } \\
\text { allows delivery of antiretrovirals using } \\
\text { macrophages allowing greater } \\
\text { entrapment efficiency and a longer } \\
\text { half-life in circulation } \\
\text { - Ideal for transdermal delivery } \\
\text { - Properties of the dendrimer based on } \\
\text { the multivalent surface } \\
\text { - The precise physicochemical properties } \\
\text { of dendrimers can be controlled during } \\
\text { synthesis by controlling the core groups, } \\
\text { the extent of branching, and the nature } \\
\text { and/or number of functional groups on } \\
\text { the surface }\end{array}$ & $\begin{array}{l}\text { - Hydrophilic drug-loading capacity of } \\
\text { liposomes is very limited due to the } \\
\text { small volume of the core, thereby } \\
\text { limiting their long-term use } \\
\text { - Physical and biologic stability of the } \\
\text { antiretroviral } \\
\text { - Low therapeutic index and } \\
\text { cytotoxicity }\end{array}$ \\
\hline $\begin{array}{l}\text { Synthetic polymeric nanoparticles } \\
\text { Nanoparticles which are prepared from synthetic } \\
\text { polymers where biological active agents are } \\
\text { dissolved, entrapped, encapsulated within natural } \\
\text { synthetic polymeric nanoparticles such as: } \\
\text { - Polylactides } \\
\text { - Polyglycolides } \\
\text { - Poly(lactide-co-glycolides) } \\
\text { - Polyanhydrides } \\
\text { - Polyorthoesters } \\
\text { - Polycyanoacrylates } \\
\text { - Polycaprolactone }\end{array}$ & $\begin{array}{l}\text { - Precise chemical composition } \\
\text { - Highly predictable physical properties } \\
\text { such as controlled rate of disassociation, } \\
\text { permeability, degradation, erosion and } \\
\text { targeting capability } \\
\text { - Nontoxic and free of leachable } \\
\text { impurities }\end{array}$ & - Biodegradable \\
\hline $\begin{array}{l}\text { Inorganic nanoparticles } \\
\text { Nanoparticles made from surface modification of } \\
\text { inorganic oxides, which are important for providing } \\
\text { diversity in size, shape, solubility, long-term stability, } \\
\text { and attachment of selective functional groups } \\
\text { - Iron oxide } \\
\text { - Quantum dots, quantum rods } \\
\text { - Gold nanoparticles } \\
\text { - Silica-based such as organically modified silica }\end{array}$ & $\begin{array}{l}\text { - Inorganic nanoparticles possess } \\
\text { outstanding optical, catalytic, electronic, } \\
\text { and magnetic properties } \\
\text { - Unique characteristics, such as nanometer } \\
\text { dimensions, tunable imaging properties, } \\
\text { and multifunctionality }\end{array}$ & $\begin{array}{l}\text { - Immunogenic } \\
\text { - Toxicity issues }\end{array}$ \\
\hline $\begin{array}{l}\text { Natural polymers } \\
\text { Nanoparticles prepared from polymers are biologic } \\
\text { active agents that can be dissolved, entrapped, } \\
\text { or encapsulated within natural polymers such as: } \\
\text { - Cellulose } \\
\text { - Gelatin } \\
\text { - Pullulan } \\
\text { - Chitosan } \\
\text { - Alginate } \\
\text { - Gliadin }\end{array}$ & $\begin{array}{l}\text { - Biodegradable mildly immunogeneic } \\
\text { nanoparticles }\end{array}$ & $\begin{array}{l}\text { - Very widely varied in physical } \\
\text { and chemical composition } \\
\text { - Biodegradable }\end{array}$ \\
\hline $\begin{array}{l}\text { Micelles } \\
\text { Amphiphilic surfactant molecules that spontaneously } \\
\text { aggregate in water into a spherical vesicle the center } \\
\text { of which is hydrophobic and therefore can sequester } \\
\text { hydrophobic drugs. Micelles have a hydrophilic or } \\
\text { polar head and a hydrophobic tail }\end{array}$ & $\begin{array}{l}\text { - Slower rate of dissociation allowing } \\
\text { retention of loaded drugs for a longer } \\
\text { period of time and, eventually, achieving } \\
\text { higher accumulation of a drug at the } \\
\text { target site }\end{array}$ & $\begin{array}{l}\text { - Drug absorption and activity } \\
\text { depends on release from micelle } \\
\text { - Surfactants irritate mucus } \\
\text { membranes }\end{array}$ \\
\hline
\end{tabular}

Further, nanomaterials can provide improved drug delivery, by virtue of their robustness, safety, and multimodality or multifunctionality. The multifunctional nanoparticle can simultaneously carry therapeutic agents to target molecules such as conjugated antibodies and imaging signal contrast agents (Figure 1). Nanoparticles can be used for delivery of antivirals to targeted infected cells within reservoirs by virtue of targeting agents and molecules. Further, these nanoparticles can also act as imaging agents, which allows for real-time tracking within cells and within the intact organism. 


\section{Schematic of the basic features of a multimodal nanoparticle complex}

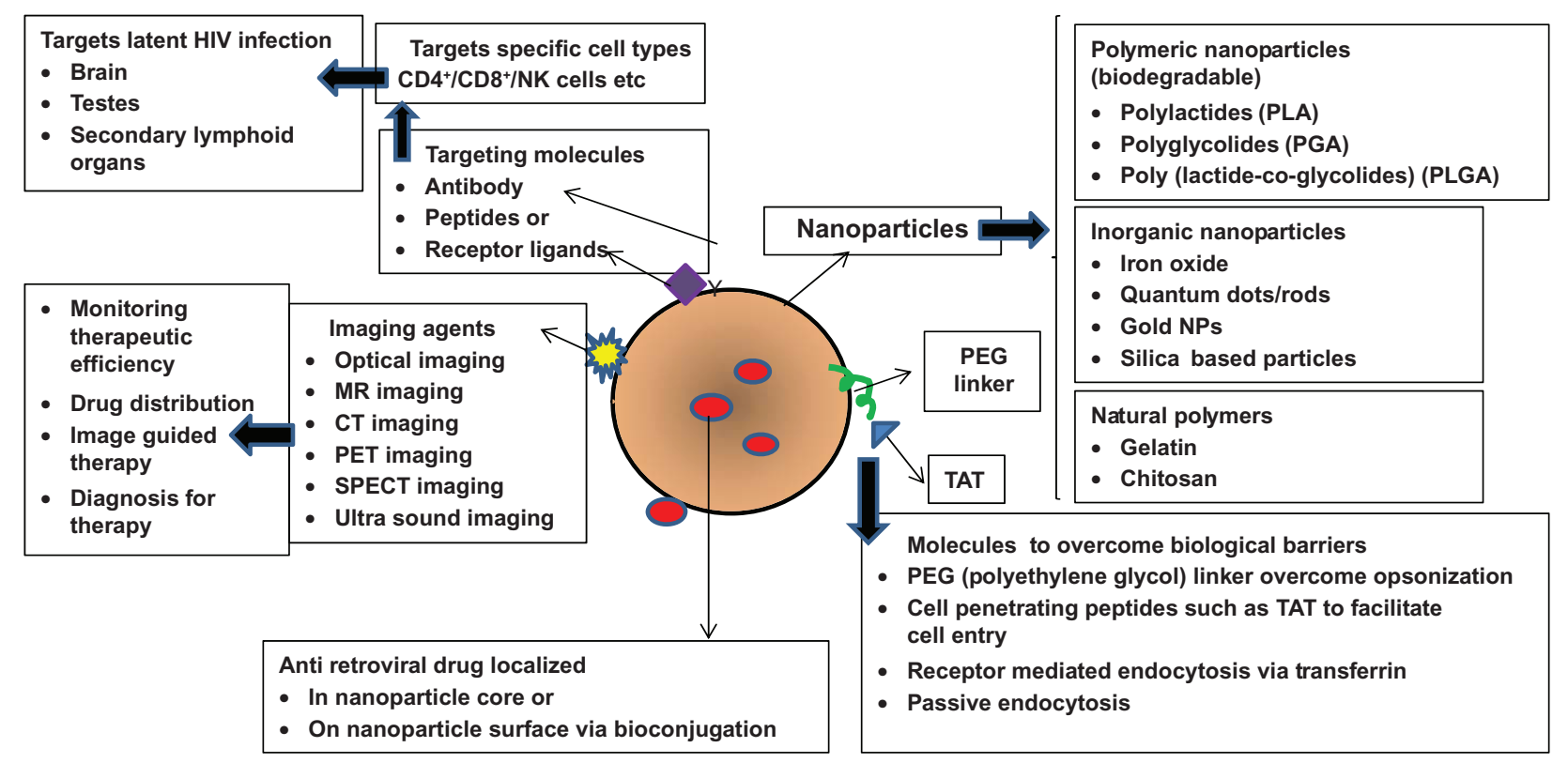

Figure I Schematic of the basic features of a multimodal nanoplex capable of targeted drug delivery.

Notes: The important components of a nanoparticle used for intracellular drug delivery which include various nanomaterials (polymeric, inorganic, or natural polymers, etc), targeting molecules (antibodies, peptides, receptor ligands), cell-penetrating peptides (to promote internalization), linkers (PEG) and the incorporated drug molecules of interest (such as the antiretroviral drugs).

Abbreviation: PEG, poly(ethylene glycol); NP, natural polymers; MR, magnetic resonance; CT, computed tomography; PET, positron emission tomography; SPECT, single photon emission computed tomography; NK, natural killer; CD4, - Cluster of Differentiation Antigen 4; CD8-, Cluster of Differentiation Antigen 8.

Advantages that nanoparticulate imaging agents have over traditional molecular imaging agents include: (a) they provide a tunable fluorescent chassis upon which targeting agents (antibodies, peptides or small molecules) can be added or changed to suit a specific need; (b) they allow for multimodality (eg, optical, magnetic resonance, and radionuclide) imaging thus permitting cross-evaluation of disease-infected sites using different imaging platforms; (c) they can be functionalized with both imaging and therapeutic abilities (d) they can be made in a large-enough size to permit multivalency ${ }^{42-45}$ (ability to bind to various ligands due to different types of surface modifications, functionalization, and bioconjugation chemistries), which results in having a potential for higher affinity binding than standard agents; and (e) they can enable imaging from the single cell level to the entire, intact organism in vivo. Nanotechnology-based delivery systems also enhance and modulate the distribution of hydrophobic and hydrophilic drugs into and within different tissue compartments. This ability of these nanoscale delivery platforms means they are suitable for clinical use in HIV-1 therapeutics. In order to have clinical applicability, nanoparticles should be stable in time with a shelf life of several months, and with a long circulating time that will assure its biodistribution, allow the passive or active targeting of a specific site within the body or cell type or cell surface, respond to stimuli such as $\mathrm{pH}$, temperature, etc, and to be also be usable as a contrast substance for medical imaging, ultrasonography, magnetic resonance imaging, computed tomography, and photodynamic therapy.

The predominant types of nanoparticles that are typically used for biological applications are (1) inorganic, and, (2) polymeric nanoparticles. Polymeric nanoparticles such as poly(lactic-co-glycolic acid) (PLGA) or polylactide, polymethacrylic acid, polyethylene glycol (PEG), and "natural" polymers such as chitosan, gelatin, or alginate, all of which are biodegradable. ${ }^{34,35}$ PEGylation coating of a nanoparticle with PEG to prevent the rapid removal of nanoparticles from the bloodstream by the mononuclear phagocytic system, increases nanoparticle circulation time and theoretically improves the therapeutic capacity of the nanoparticle. ${ }^{36}$ Advances in polymerization chemistries and the application of reactive, efficient and orthogonal chemical modification reactions have enabled the engineering of multifunctional polymeric nanoparticles with precise control over the architectures of the individual polymer components, to direct their assembly and subsequent transformations into nanoparticles of selective overall shapes, sizes, internal morphologies, external surface charges and functionalities. Further, incorporation of certain functionalities can modulate 
the responsiveness of these nanostructures to specific stimuli through remote activation. ${ }^{34,35-50}$

Inorganic particles are much smaller, typically less than $20 \mathrm{~nm}$, and circulate easily in the bloodstream and are easily cleared via renal excretion. ${ }^{42-46}$ Silica-based nanoparticles such as organically modified silica are known for their low toxicity and biocompatibility for targeted imaging and therapy ${ }^{47-50}$ Gold nanoparticles (GNP) are an attractive drugdelivery vector due to the ease with which biomolecules such as protein or DNA can be attached to the gold surface using thiol chemistry. This process can also allow attachment of multiple targeting or functional groups to the nanoparticle surface to produce a multifunctional nanoparticle. Quantum dots (QDs) that have a colloidal core/shell such as CdSe/ $\mathrm{ZnS}, \mathrm{CdSe} / \mathrm{CdS} / \mathrm{ZnS}, \mathrm{CdTe} / \mathrm{CdSe}$, and $\mathrm{InP} / \mathrm{ZnS}$ are also commonly synthesized for biomedical applications. ${ }^{51-54} \mathrm{QDs}$ are unique probes due to their special properties (brightness, photostability, narrow-band emission, and broadband absorption), and they have excellent biocompatibility for real-time imaging. ${ }^{53}$ When QDs are functionalized with ligands, they enable the recognition of specific targets and allow tracking of dynamic functional processes with a great sensitivity for extended periods of time. Although both GNP and QDs can be easily functionalized, these nanoparticles may accumulate in tissues over time because they are not biodegradable and the long-term effects of accumulation of these nanoparticles are unknown. Table 2 summarizes the pros and cons of the different types of nanomaterials used in biomedical applications.

Nanotechnology can revolutionize the field of HIV medicine since it can impact the treatment and prevention of HIV/AIDS, and also improve diagnosis. The current review will focus more on the pivotal role of nanotechnology in HIV-1 therapeutics, particularly focusing on nanotherapeutic approaches that increase the efficacy of the existing antiretrovirals in targeting sequestered viral reservoirs.

\section{The HIV-I lifecycle and traditional antiretroviral therapy}

HIV enters the cell via endocytosis and fuses with an endosome, then the viral RNA genome is released into the cell where it undergoes reverse transcription followed by integration of the proviral DNA into the host chromosome. Subsequent to translation, immature viral particles egress the cell by assembly of the viral proteins at the cell membrane, followed by virion budding, which results in the generation of a mature virus that can infect other cells. Types of antiretroviral drugs used in treatment of HIV include: reverse transcriptase inhibitors that act by blocking the activity of the reverse transcriptase enzyme, thus preventing the construction of viral DNA; nucleoside analog reverse transcriptase inhibitors, which act by incorporation into the viral DNA leading to chain termination; nonnucleoside analog reverse transcriptase inhibitors, which block the binding potential of the reverse transcriptase enzyme; protease inhibitors, which interfere with viral assembly by blocking the protease enzyme necessary for cleaving the nascent viral proteins for final assembly into new virions; fusion inhibitors, which block the fusion of the virus with the cell membrane and subsequent entry into the host cells; integrase inhibitors, which block the integration of viral DNA into the host cell DNA; and finally, entry inhibitors, which bind to HIV-1 coreceptors on the viral membrane surface used in the entry of the virus into the host cell. Highly effective antiretroviral therapy (HAART) is a combination of three or more of the above drug classes, which is efficient in controlling infection and disease progression and minimizes the development of resistant strains by attacking the viral infection more aggressively.

\section{Nanoformulations of antiretrovirals}

Current HIV-HAART therapy exposes the entire body to multiple drugs at high doses, resulting in enormous side effects, which often limit therapy due to adherence issues leading to unsuccessful therapy. Adherence to drug regimens that constitute complexities of frequent administration and high dosages are crucial in the treatment of HIV infection. Development of targeted drug-delivery approaches for AIDS therapy will improve the safety and efficacy of anti-HIV drugs by reducing the dosage and adverse effects associated with them. The systemic distribution pattern of nanocarrierbased HIV drugs should be dictated by the properties of the nanocarrier rather than the antiretroviral drug and an ideal nanocarrier-based HIV drug should deliver higher drug concentrations and have increased residence time at target cells whereby enhanced viral load reduction can be achieved. Surface modification of nanocarriers by modulating polymer characteristics on the nanocarrier surface allows controlled release of an anti-HIV drug from nanocarriers to achieve the desired therapeutic level in target tissue..$^{11,14-22}$

Development of a biocompatible nanoformulation that can target HIV-1 in sequestered sites requires the use of functionalized nanoparticles that are engineered to deliver drugs to specific tissue or cell compartments. ${ }^{28}$ Although efficient internalization within the cells and selective targeting are the major aims of such a drug carrier, ideally it should 
also have the characteristic of long circulation time in blood and self-regulation of drug release, and have low toxicity and minimal side effects. In general, the sizes of such nanoparticlebased delivery platforms range from 10 to $1000 \mathrm{~nm}$ and consist of therapeutic agents within the nanoparticle system. ${ }^{18-20}$ Such a nanoparticle system increases solubility and enhances stability of mostly poorly water-soluble therapeutic agents such as antiretroviral drugs which are mostly hydrophobic, and protect them from interacting with nonspecific sites, thereby reducing toxicity. Table 3 lists the various antiretroviral nanoformulations used as HIV-1 therapeutics.

\section{Targeted drug delivery of antiretrovirals}

Targeted delivery of antiretrovirals to HIV-1-infected T-cells and macrophages would improve the efficacy of antiviral drugs, reduce toxicity, reduce HIV-resistance frequency, and decrease viral production. However, the specificity of intracellular delivery and transport is related to many factors including the type and number of targeting ligands required for optimal cellular uptake. Various mechanisms of intracellular delivery of the antiretroviral drug include passive diffusion of free drug, nonspecific phagocytosis of a nanocarrier, pinocytosis and receptor-mediated endocytosis. Another advantage of nanocarriers includes its ability to bypass the multidrug-resistant transporters, which may efflux drugs entering freely through the plasma membrane. ${ }^{14-29}$

Inorganic solid lipid nanoparticles liposomes, polymeric micelles, dendrimers, cyclodextrins, and cell-based nanoformulations have been studied for delivery of drugs intended for HIV prevention or therapy. ${ }^{43}$ For anti-HIV drugs to be effective, adequate distribution to specific sites in the body must be achieved, and effective drug concentrations must be maintained at those sites for the required period of time. ${ }^{55}$ For effective delivery of anti HIV-1 nanotherapy, an optimal drugdelivery nanocarrier vehicle must be generated that should be of a precise geometry, whose surface (ie, zeta potential, stealth ligands), drug/biomolecule (antiretrovirals, oligonucleotides, proteins, small interfering RNA [siRNA], RNA, imaging agents) encapsulation efficiency and release, surface chemistries (targeting antibodies, PEG chains, metal chelators), and spatial distribution of ligands must be well engineered. Targeted nanocarrier delivery involves (1) the recognition of HIV-infectable target cells and tissues; (2) the ability to reach these sites; and (3) the ability to deliver multiple therapeutic agents. ${ }^{14-24}$

Macrophages have been used as cellular transporters for antiretroviral nanoparticles or nanoformulated antiretroviral drugs (nano-ART) distribution and that the efficacy of antiretroviral medications can be significantly improved by repackaging them into nanoparticles. ${ }^{24,29}$ Nowacek and

Table 3 Summary of antiretroviral drugs used in HIV-I nanotherapeutics

\begin{tabular}{|c|c|c|c|}
\hline Antiretroviral drug & Nanoparticle type & Stage & References \\
\hline $\begin{array}{l}\text { Stavudine (D4T), } \\
\text { delavirdine (DLV), } \\
\text { saquinavir (SQV) }\end{array}$ & $\begin{array}{l}\text { Methylmethacrylate-sulfopropylmethacrylate } \\
\text { (MMA-SPM) nanoparticles with grafted RMP-7 } \\
\text { (RMP-7/MMA-SPM nanoparticles) }\end{array}$ & Preclinical & Kuo and Lee ${ }^{100}$ \\
\hline Ampenavir & Transferrin (Tf)-conjugated quantum dots & Preclinical & Mahajan et $\mathrm{al}^{71}$ \\
\hline Dapivirine & Poly( $\varepsilon$-caprolactone) nanoparticles & Preclinical & das Neves et al ${ }^{101}$ \\
\hline Ritonavir & Tat-peptide-conjugated pitonavir nanoparticles & Preclinical & Borgmann et al ${ }^{16}$ \\
\hline $\begin{array}{l}\text { Indinavir, ritonavir, } \\
\text { atazanavir, and efavirenz }\end{array}$ & $\begin{array}{l}\text { Monocyte-derived macrophages-nanoparticle } \\
\text { interactions }\end{array}$ & Preclinical & Nowacek et $\mathrm{al}^{57}$ \\
\hline D4T, DLV, SQV & $\begin{array}{l}\text { Lipids: Compritol } 888 \text { ATO, tripalmitin, and cacao butter } \\
\text { stabilized by L- } \alpha \text {-phospatidylcholine, cholesteryl hemisuccinate, } \\
\text { and taurocholate to form solid lipid nanoparticles }\end{array}$ & Preclinical & Kuo and Chung ${ }^{102}$ \\
\hline SQV & $\begin{array}{l}\text { Nanoparticles with ternary components of polyethyleneimine, } \\
\text { poly( } \gamma \text {-glutamic acid), and poly(lactide-co-glycolide acid) (PLGA) }\end{array}$ & Preclinical & Kuo and $\mathrm{Yu}$ is ${ }^{103}$ \\
\hline $\begin{array}{l}\mathrm{d} 4 \mathrm{~T}-\text { nucleoside reverse } \\
\text { transcriptase inhibitor }\end{array}$ & $\begin{array}{l}\text { Chitosan-O-isopropyl-5'-O-d4T monophosphate conjugate } \\
\text { with a phosphoramidate linkage }\end{array}$ & Preclinical & Yang et al Is $\mathbf{s}^{104}$ \\
\hline SQV & Tf-conjugated quantum rods & Preclinical & Mahajan et $\mathrm{al}^{76}$ \\
\hline Ritonavir, lopinavir, and efavirenz & PLGA nanoparticles & Preclinical & Destache et al $\left.\right|^{105}$ \\
\hline Rilpivirine & Poloxamer 338/TPGS 1000 & Preclinical & Baert et al ${ }^{106}$ \\
\hline Stavudine & Mannose- and galactose-targeted liposome & Preclinical & Dou et $\mathrm{al}^{56}$ \\
\hline Efavirenz & Mannose-targeted dendrimer & Preclinical & Dou et $\mathrm{al}^{56}$ \\
\hline Lamivudine & Mannose-targeted dendrimer & Preclinical & Wan et al ${ }^{107}$ \\
\hline Zidovudine & Mannose-targeted liposome & Preclinical & Kaur et al ${ }^{108}$ \\
\hline Indinavir & Liposome-laden macrophages & Preclinical & Dou et al ${ }^{109}$ \\
\hline
\end{tabular}

Abbreviations: SQV, saquinavir; DLV, delavirdine; D4T, stavudine; PLGA, poly lactide-co-glycolide acid; Tf, transferrin; MMA-SPM, ethylmethacrylate-sulfopropylmethacrylate; RMP-7, bradykinin agonist; Compritol 888ATO, National Formulary (NF) glyceryl nehenate; TPGS, tocopheryl polyethylene glycol succinate. 
Gendelman have shown that a single intravenous dose of the nano-ART can elicit high-sustained tissue and plasma drug levels of antiretroviral drugs in the reticuloendothelial system and brain. ${ }^{26}$ Nano-ART can be taken up within minutes by circulating monocytes and released in tissues over a period of 2 weeks. ${ }^{56-60}$ Theoretically, cell-based nano-ART would travel to sites of inflammation and release $\operatorname{drug}(\mathrm{s})$ slowly with limited tissue toxicities. Such a drug-delivery system can revolutionize HIV-1 therapeutics and can particularly target virus sequestration. A recent study suggested that nanoART has tremendous translational potential since it allows sustained delivery and targeted efficacy of the antiretroviral drugs with limited systemic toxicities, indicating that nanoART has the potential to improve drug adherence and reduce viral resistance in HIV-1-infected subjects. ${ }^{58}$.

Studies by Kadiu et al show that both particle integrity and antiretroviral activity are maintained during subcellular transport of antiretroviral nanoformulations. ${ }^{61}$ Recently, Shegokar and Singh have shown that nevirapine nanosuspensions that were surface modified with serum albumin, polysaccharide, and polyethylene glycol had enhanced bioavailability and targeting potential. ${ }^{62}$ They also demonstrated active delivery of stavudine-loaded solid lipid nanoparticles to lymphatic tissues showing increased lymphatic drug levels and organ distribution studies demonstrating efficiency of the developed nanoparticles for prolonged residence in splenic tissues ${ }^{62}$. Polymeric systems consisting of nanosuspensions of rilpivirine that were PEGylated and stabilized by other polymers showed that single-dose administration of this nanosuspension resulted in sustained release of the drug and lowered dosing frequency. ${ }^{63-65}$ Tat-peptide-conjugated ritonavir-loaded nanoparticles effectively controlled viral replication in HIV-1-infected brain by targeting monocytederived macrophages and other neural cells within the brain. ${ }^{66}$ A study that evaluated pharmacokinetics of free antiretroviral drugs ritonavir, lopinavir, and efavirenz with poly(D,L-lactide-co-glycolide) nanoparticle-conjugated antiretroviral drugs (AR-NPs) showed that antiretroviral drug concentrations from AR-NPs are sustained for 28 days in vivo and anti-HIV inhibition was comparable to that of free drugs in vitro. ${ }^{67,68}$ Nevirapine-loaded liposomal formulations improve targeted delivery of the antiretroviral drugs to select cell compartments and alleviated systemic toxic side effects. ${ }^{69}$ Carbon nanotubes show promise as anti-HIV-1 therapeutics. ${ }^{70}$ All the above-mentioned studies are in various preclinical stages and significant amount of experimental and clinical validation needs to be done before nanotherapy for HIV become a reality in the clinics. Several additional nanotechnology systems for delivery of antiretroviral drugs have been outlined in recent reviews. ${ }^{1-28}$ We have made a comprehensive list of the antiretroviral used in HIV therapy in Table 3 .

\section{Mechanisms involved in nanoparticle based intracellular drug delivery}

The mechanisms involved in nanoparticle-based intracellular drug delivery include (i) passive diffusion of free drug, (ii) nonspecific phagocytosis of the nanocarrier, (iii) nanocarrier uptake by pinocytosis, and (iv) receptor-mediated endocytosis. More than one mechanism may be involved in intracellular drug delivery. Nanoparticles may reside within lysosomal compartment following endocytosis, and premature drug release within this acidic compartment may cause drug degradation and render treatment ineffective. Therefore, cytosolic delivery and drug release within the cytosolic compartment will allow for the most effective therapy. ${ }^{15-20}$

\section{Targeting HIV-I in the brain}

Most of the currently used antiretroviral drugs are effective in reducing viral load in the systemic circulation, but cannot eradicate infection from tissue reservoirs such as the brain. Nanoparticles offer great promise for neurotherapeutics. ${ }^{25-29}$ Nanocarriers provide a means to overcome cellular and anatomical barrier such as the blood-brain barrier (BBB) to drug delivery. ${ }^{54}$ The BBB inhibits the transport of antiretroviral drugs to the brain by the presence of tight endothelial cell junctions and efflux transporters such as P-glycoprotein (P-gp), a multidrug-resistant protein. Nanocarriers bypass multidrugresistant transporters such as P-gp that may efflux drugs entering freely through the plasma membrane. The Pluronic ${ }^{\mathbb{R}}$ (BASF - The Chemical Company, Florham Park, NJ) are block copolymers based on ethylene oxide and propylene oxide that enhance the in vivo efficacy of antiretrovirals ${ }^{59}$ by influencing their distribution to sites protected by efflux mechanisms, such as the BBB, and possibly increase the brain exposure of these drugs resulting in suppression of viral replication. Pluronic P85 has shown to inhibit the interaction of P-gp with nelfinavir and saquinavir. ${ }^{59}$ An elegant study using a nanosuspension of indinavir showed that macrophages loaded with this nanosuspension could bring about a measurable reduction in antiviral load in the brains of an HIV-infected rodent model. ${ }^{56}$ Magnetic nanoformulations have been used for targeting active nucleotide analog reverse transcriptase inhibitors to the brain by application of an external magnetic force and thereby eliminating the brain HIV reservoirs. ${ }^{68}$ 
Our group has recently shown that conjugation with transferrin ( $\mathrm{Tf}$ ), allows antiretroviral drug-loaded nanoformulations to permeate across biological barriers such BBB via a receptor-mediated transport mechanism. We stably incorporated saquinavir within Tf-conjugated quantum rods (QRs), which are novel nanoparticles with unique optical properties and evaluated antiviral efficacy and the transversing ability of the QR-Tf-saquinavir nanoformulation across an in vitro model of BBB (Figure 2). We have also observed that amprenavir-Tf-conjugated quantum dot (QD) (Tf-QD-amprenavir) nanoplexes cross the BBB via receptor-mediated endocytosis and release the amprenavir. The activity of amprenavir remains unaltered when conjugated to the QD or the transporter molecule, $\mathrm{Tf}^{71}$ The high photostability of QDs emitting in the near-infrared spectral region facilitates the monitoring of this transport process in real-time via high-resolution optical imaging. ${ }^{772-75}$ Thus a QD/QR-based nanoplatform facilitates not only the delivery of an antiretroviral drug across the $\mathrm{BBB}$ via interaction with endogenous transferrin receptors on the BBB but also allows the real-time monitoring of this transendothelial migration process via optical imaging. We have demonstrated that antiretroviral drug-loaded nanoparticles can deliver effective therapeutics across the BBB and that our nanoformulation has great potential in the treatment of neuro-AIDS and other neurological disorders. ${ }^{71,75,76}$

\section{Anti-HIV-I siRNA therapeutics}

Recent advances in the field of nanotechnology offer an unprecedented opportunity to enhance the power of siRNAmediated gene therapy by providing both an efficient delivery system as well as targeted specificity. siRNA-mediated knockdown of gene-specific messenger RNA (mRNA) levels is a great therapeutic strategy, ${ }^{29}$ in which double-stranded RNAs are cleaved by the cellular nuclease Dicer into short 21-22-mer fragments referred to as siRNA, which enter a ribonuclease protein complex called the RNA-induced silencing complex. This complex mediates a specific degradation of the corresponding mRNA. Nanoparticles can form stable complexes with siRNAs, called nanoplexes, which can overcome all the impediments associated with siRNA in the free form. A nanoplex is a generic term for a nanoparticle complexed to another biological component, which could be a drug, an siRNA, a imaging agent and antibody, a peptide, etc.

siRNA technology is a novel method to achieve complete and persistent knockdown of gene expression. Challenges to efficient siRNA delivery and activity include: (1) design of effective siRNA sequences; (2) bioconjugation with a safe and efficient delivery system such as nanoplexes; (3) formulation of a nanoplex with favorable pharmacokinetics; (4) stabilization of the siRNA
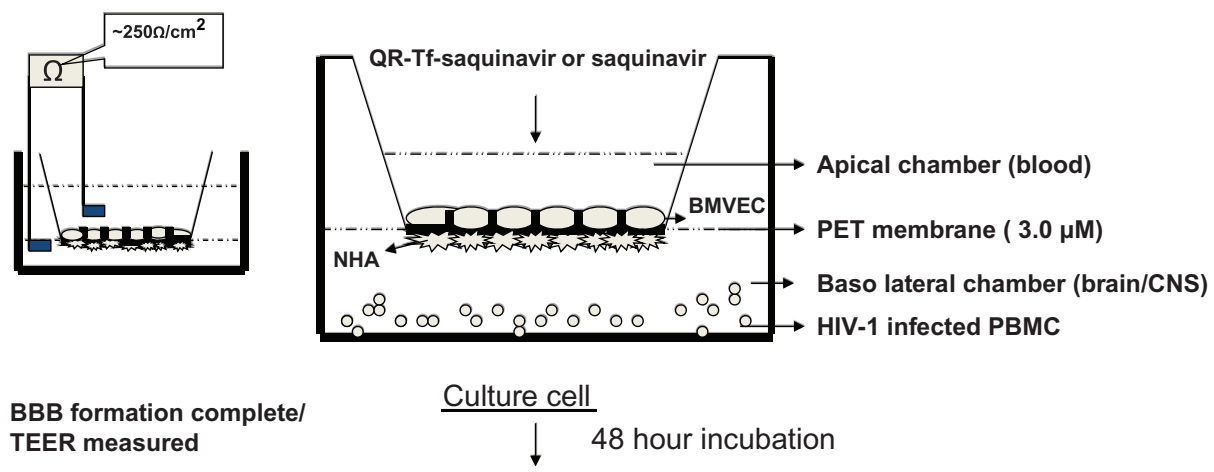

- LTR/RU5 gene expression using Q-PCR in HIV-1 infected PBMC isolated from lower chamber

- p24 quantitation in media using ELISA kit

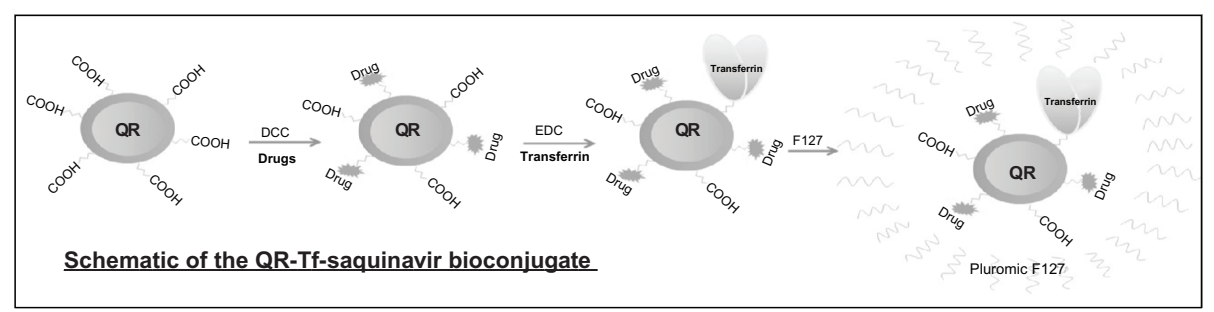

Figure 2 Schematic of the QR-Tf-saquinavir bioconjugate and the transversing potential of the QR-Tf-saquinavir nanoformulation across an in vitro BBB. Copyright @ 2010 , Bentham Science.

Reproduced with permission from Mahajan SD, Roy I, Xu G, et al. Enhancing the delivery of anti retroviral drug "Saquinavir" across the blood brain barrier using nanoparticles. Curr HIV Res. 2010;8(5):396-404. ${ }^{75}$

Abbreviations: BBB, blood-brain barrier; QR, quantum rods Tf, transferrin; PET, polyethylene terephthalate; CNS, central nervous system; PBMC, peripheral blood mononuclear cells; NHA, normal human astrocytes; Baso, basophil; HIV-I, human immunodeficiency virus-I; BMVEC, brain microvascular endothelial cells; TEER, transendothelial electric resistance; LTR, long terminal repeat; PCR, polymerase chain reaction, ELISA, enzyme-linked immunosorbent assay. 
in biological systems; (5) efficient delivery and entry of the siRNA nanoplex into target cells; and (6) prevention of endosomal escape of siRNA nanoplexes from the intracellular milieu. Additionally, the siRNA nanoplex should have minimal effects on nontarget genes and should avoid inadvertent stimulation of the immune system. ${ }^{77,78}$ Delivery is a key determinant as to whether or not RNA interferencebased therapeutics will have clinical relevance and delivery encompasses extracellular transport of the nanoplex to target cells, its intracellular RNA trafficking, and processing. ${ }^{79-89}$ Gold nanoparticles are particularly attractive for therapeutic applications due to their biocompatibility and ease of complex formation with biomolecules. Gold nanorods (GNR) have far-reaching potential for the study of intracellular processes at the single-molecule level, using high-resolution cellular imaging, long-term observation of cell trafficking in vivo, and gene silencing. ${ }^{73,74}$ The hydrodynamic size of these GNR-nanoplexes under physiological condition is $<100 \mathrm{~nm}$, making them ideal as intracellular delivery agents. Gold nanoparticles have been used for more than a decade as a gene carrier for plasmid DNA and oligonucleotides, but recently our group was the first to report the use of GNR for the delivery of siRNA against dopamine- and cyclic-adenosine monophosphate-regulated phosphoprotein of molecular weight 32,000 (DARPP-32) in vitro. ${ }^{90}$ Figure 3 represents a schematic of the cationically charged PEGylated GNRs electrostatically coupled with negatively charged siRNA to form stable nanoplexes. We evaluated these nanoparticles as nonviral gene carriers by investigating their specificity and efficiency in achieving DARPP-32 gene silencing in primary dopaminergic neuronal cells, which are typically difficult to transfect. These nanoplexes were also found to transmigrate across an in vitro model of the BBB without compromising the integrity of the barrier, while retaining their gene-silencing efficiency. These results have enormous implication in the treatment of drug addiction in HIV-1-infected drug-abusing patients. These observations have further underscored the tremendous benefits that nanotechnology can offer towards the safe and efficient delivery of siRNA-based therapeutics in the brain and other organs.

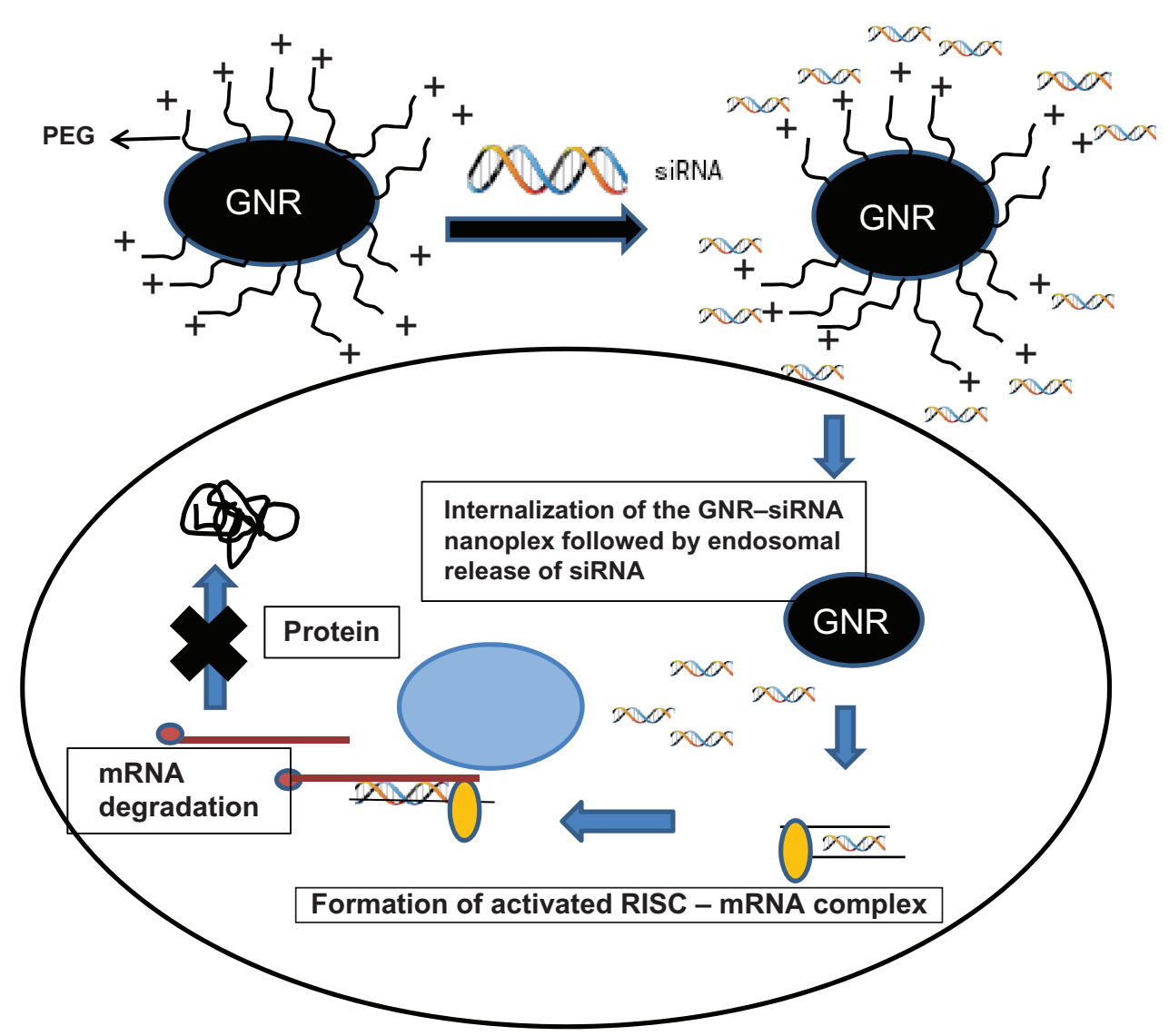

Figure 3 Schematic of cationically charged PEGylated GNRs electrostatically coupled with negatively charged siRNA to form stable nanoplexes.

Notes: The GNR-siRNA nanoplex can bring about the specific knockdown of a gene of interest. The siRNAs are $21-23$ bp double-stranded RNAs that can initiate the enzymatic breakdown of specific mRNAs in a cell through an RNA-induced silencing complex.

Abbreviations: GNRs, gold nanorods; siRNA, small, interfering RNA. 
To enhance the cellular uptake of siRNA molecules, cell-penetrating peptides (CPP)-mediated siRNA delivery employing a disulfide bond formation between peptide transduction domain (PTD)/CPP and siRNA is typically utilized. Some of the most well characterized CPPs are TAT peptide, penetratin, transportan, polyarginine and MPG. Recently, studies ${ }^{11,92}$ evaluated the in vivo efficacy of structurally flexible, cationic PAMAM dendrimers as a siRNA-delivery system in a humanized mouse model for HIV-1 infection. They have also developed novel dual inhibitory anti-glycoprotein-120 aptamer-siRNA chimera with potent anti-HIV activities and have further constructed a chimerical RNA nanoparticle that contains a HIV gp120binding aptamer escorted by the packaging RNA (pRNA) of bacteriophage phi29 DNA-packaging motor. These pRNAaptamer chimeras specifically bind to and are internalized into cells expressing HIV gp120 and inhibit HIV function by blocking viral infectivity. This nanoplex represents a potential HIV-1 inhibitor, and provides a cell-type-specific siRNA-delivery vehicle, showing promise for systemic anti-HIV therapy. ${ }^{87}$ Our group demonstrated an almost $90 \%$ viral suppression using a nanoparticle $(\mathrm{QR})$-conjugated well validated siRNA (si510) that targets the poly-A/TAR (transactivator of the HIV-1 LTR) site and suppresses viral replication in the THP-1 monocytic cells. ${ }^{55}$ Dendrimers have also been successfully used to deliver and transfect siRNA to various HIV-infected human cell types resulting in gene silencing without causing cytotoxicity. ${ }^{88,89}$

We have observed a decrease in endothelial permeability, as reflected by reduction of transendothelial resistance across an in vitro BBB on treatment with QR-conjugated matrix metalloproteinase-9 (MMP-9)-siRNA due to downregulating the expression of MMP-9 gene in brain microvascular endothelial cells that constitute the BBB. ${ }^{90}$ Thus siRNA therapeutics for HIV infection have been demonstrated in many studies, but limitations of this strategy include successful strategies to deliver siRNA to the desired target cells such as $\mathrm{T}$ cells, macrophages, dendritic cells, and tissues. Despite these limitations, siRNA therapeutics possesses great potential in HIV therapy.

\section{Nanotechnology-based immunotherapy for HIV}

Attempts at creating an effective HIV vaccine have been unsuccessful because immune cells that are needed for vaccine effectiveness are destroyed by the virus. ${ }^{60}$ Nanoparticles can improve delivery of antigens to enhance the immune response and can encapsulate antigens in their core from which antigen-presenting cells (APCs) can process and present antigens to $\mathrm{CD} 4^{+}$and $\mathrm{CD} 8^{+} \mathrm{T}$ cells or facilitate $\mathrm{B}$ cells to generate humoral responses. ${ }^{92-95}$ Various polymeric and lipid-based nanoparticles have been used to deliver DNA-, protein-, or peptide-based antigens in vivo, which elicit strong cellular, humoral, and mucosal immune responses. However, no effective vaccine strategy has emerged in spite of promising preliminary results. ${ }^{14-18}$

\section{Nanoparticles as adjuvants in HIV vaccine}

The most commonly used adjuvants in vaccines are aluminum-based compounds such as aluminum hydroxide. Aluminum hydroxide adjuvants stimulate the production of specific types of immune cells called APCs. These APCs pick up the antigen and present it to $\mathrm{T}$ cells. Various adjuvants are considered for use with candidate AIDS vaccines. Nanomaterials can act as adjuvants in the development of the AIDS vaccine due to their unique physicochemical properties. ${ }^{27}$ Surface-engineered GNRs provide a multimodal nanoplatform for vaccine neoadjuvant-delivery systems in the treatment of AIDS. ${ }^{14,24,93}$ Nanoparticles can also be designed to provoke an immune response by either direct immunostimulation of APCs or delivering antigens to specific cellular compartments. ${ }^{94}$ To eliminate an immune response to the nanoparticle itself, the particle size is important since microparticles are rapidly cleared by the reticuloendothelial system, while nanoparticles have prolonged circulation time and are efficient drug, enzyme, and protein carriers by any route of administration.

Polymeric biodegradable nanoparticles such as $\operatorname{poly}(\gamma-$ glutamic acid) can be used as a stable protein-based antigen carrier and can be utilized for antigen delivery and other immunostimulatory activities. Wang et $\mathrm{al}^{79}$ have shown that $\gamma$-polyglycolides ( $\gamma$-PGA) nanoparticles have a capacity comparable to that of complete Freund's adjuvant (CFA) in inducing p24-specific serum antibody by predominantly activating p24-specific interferon- $\gamma$-producing T cells. Thus, $\gamma$-PGA nanoparticles encapsulating various antigens may have great potential as novel and efficient protein-based vaccines against HIV-1 infection. ${ }^{11,27,95}$ Several liposome-based systems using a variety of HIV-1 antigenic peptides such as gp160, gp41, gp120, p24, tat, gag, env, and rev have been evaluated for HIV vaccine delivery, however none of them have been able to elicit a broad neutralizing antibody response. ${ }^{32-42}$ Although several nanoparticle-based immunotherapeutic clinical trials for treatment have been performed, none of them have provided consistent clinical improvements for patients. 


\section{Nanoparticles improve HIV-I diagnostics}

The availability of sensitive and specific detection methods to identify HIV-1 in clinical specimens is highly desirable. GNPs have been used for improving detection sensitivity of HIV-1 p24 antigen assay. A GNP-based assay can detect HIV-1 p24 antigen at levels as low as $0.1 \mathrm{pg} / \mathrm{mL}$ and these assays offer 100-150-fold enhancement in the detection limit and detected HIV-1 infection 3 days earlier than the traditional colorimetric enzyme-linked immunosorbent assay (ELISA) ${ }^{96,97}$ Nanolithography was used to generate nanoscale patterns of antibodies against the HIV-1 p24 antigen on a gold surface. HIV-1 p24 antigen in plasma obtained directly from HIV-1-infected patients was hybridized to the antibody array in situ, and the bound protein was hybridized to a gold antibodyfunctionalized nanoparticle probe for signal enhancement. The nanoarray is a three-component sandwich assay that measures less than $0.025 \mathrm{pg} / \mathrm{mL}$ of HIV-1 p24 levels suggesting that this nanoarray-based assay can exceed the limit of detection of a conventional ELISA by more than a 1000 -fold. Such assay systems can have a significant impact on HIV diagnostics. ${ }^{97}$

\section{Prevention of sexual transmission of HIV using nanoparticle-based microbicides}

Nanoparticles that also provide a delivery strategy for targeted or controlled delivery to the vagina using topical microbicides, which can result in HIV prevention, are urgently needed to curb the rate of new infections. ${ }^{98,99}$ Dendrimers, PLGA nanoparticles, and cholesterol-conjugated siRNA have been evaluated for delivery of microbicides against HIV and although in vivo studies in mice suggest proximal and distal site topical delivery of the microbicides, issues of deep penetration into the epithelial barrier and issues with degradation in the mucus physiological environment remain to be resolved. ${ }^{13,30,31,36-41,100-109}$

\section{HIV-I nanotherapy: an emerging technology, its promise, and limitations}

Nanotechnology can impact HIV therapy at several levels. (1) Nanoparticles by themselves have therapeutic effects since they can penetrate and neutralize the virus, by structural interference with viral assembly and thereby inhibit viral replication. (2) Nanotechnology allows improved delivery platforms for systemic delivery of antiretroviral drugs, by allowing controlled release of antiretroviral drugs in circulation, thereby enhancing their half-lives and effectiveness, all of which can have a major implication in improving adherence to drugs in HIV infected patients. (3) Gene immunotherapy can be significantly improved using various nanomaterials. Nanotechnology-based vaccines have the ability to target specific immune cells, eliciting a controlled and sustained HIV-1 specific antibody and cellular immune response. Nonviral delivery of siRNA has tremendous translational potential and although delivery of siRNA to HIV-specific cells has been demonstrated, additional research on the safety and efficacy of siRNA nanotherapeutics has to be done before these therapies are used in the treatment of HIV/AIDS.

Our group has been working in the area of nanomedicine, particularly in the context of HIV-1 therapy, for a couple of years and has used polymeric, nonpolymeric, and lately biodegradable materials for targeted drug delivery of antiretrovirals, siRNA therapeutics, and certain aspects of HIV-1 immunotherapy. All these materials represent the diversity of nanomedicine applications and although HIV-1 nanotherapy has enormous promise, several challenges remain to be addressed.

There has been tremendous development over the last decade with respect to the types of nanomaterials available for biomedical applications; an enormous range of shapes, sizes, surface modifications, and functional modality options have been developed, but the main issue of their interaction in biological systems remain to be resolved. Although, some degree of success is observed in vitro studies, many studies have not moved beyond the preclinical stage due to challenges that include unwarranted interactions with plasma proteins in systemic circulation, inability to overcome biological barriers, nonspecific distribution in the body, and aggregation and accumulation within specific organs such as kidney resulting in toxicity. Thus toxicity of nanomaterials, stability in physiological conditions, and a lack of adequate reliable and affordable HIV/AIDS animal models for in vivo studies during these nanoparticles are some of the key obstacles in HIV-1 nanotherapeutics.

In spite of these limitations, nanotechnology holds great potential for impact in the field of HIV treatment and prevention. Multidisciplinary research across disciplines of biology, medicine, chemistry, pharmaceutical sciences, and bioengineering will revolutionize the field of nanomedicine in the near future.

\section{Disclosure}

The authors report no conflicts of interest in this work. 


\section{References}

1. Bruchez M Jr, Moronne M, Gin P, Weiss S, Alivisatos AP. Semiconductor nanocrystals as fluorescent biological labels. Science. 1998;281(5385):2013-2016.

2. Chan WC, Nie S. Quantum dot bioconjugates for ultrasensitive nonisotopic detection. Science. 1998;281(5385):2016-2018.

3. Pardridge WM. Gene targeting in vivo with pegylated immunoliposomes. Methods Enzymol. 2003;373:507-528.

4. Shi N, Boado RJ, Pardridge WM. Receptor-mediated gene targeting to tissues in vivo following intravenous administration of pegylated immunoliposomes. Pharm Res. 2001a;18(8):1091-1095.

5. Shi N, Zhang Y, Zhu C, Boado RJ, Pardridge WM. Brain-specific expression of an exogenous gene after i.v. administration. Proc Natl Acad Sci U S A. 23, 2001;98(22):12754-12759.

6. Vinogradov $\mathrm{S}$. The second annual symposium on nanomedicine and drug delivery: exploring recent developments and assessing major advances. August 19-20, 2004, Polytechnic University, Brooklyn, NY, USA. Expert Opin Drug Deliv. 2004;1(1):181-184.

7. Yong, KT, Qian J, Roy I, et al. Quantum rod bioconjugates as targeted probes for confocal and two-photon fluorescence imaging of cancer cells. Nano Lett. 2007;7(3):761-765.

8. Lee DE, Koo H, Sun IC, Ryu JH, Kim K, Kwon IC. Multifunctional nanoparticles for multimodal imaging and theragnosis. Chem Soc Rev. 2012;41(7):2656-2672.

9. Lammers T, Aime S, Hennink WE, Storm G, Kiessling F. Theranostic nanomedicine. Acc Chem Res. 2011;44(10):1029-1038.

10. Kim BY, Rutka JT, Chan WC. Nanomedicine. N Engl J Med. 2010; 363(25):2434-2443.

11. Parboosing R, Maguire GEM, Govender P, Kruger HG. Nanotechnology and the treatment of HIV infection. Viruses. 2012;4:488-520.

12. Armstead AL, Li B. Nanomedicine as an emerging approach against intracellular pathogens. Int J Nanomedicine. 2011;6:3281-3293.

13. Lara HH, Garza-Treviño EN, Ixtepan-Turrent L, Singh DK. Silver nanoparticles are broad-spectrum bactericidal and virucidal compounds. J Nanobiotechnology. 2011;9:30.

14. das Neves J, Amiji M, Sarmento B. Mucoadhesive nanosystems for vaginal microbicide development: friend or foe? Wiley Interdiscip Rev Nanomed Nanobiotechnol. 2011;3(4):389-399.

15. Kim JM, Han SH. Immunotherapeutic restoration in HIV-infected individuals. Immunotherapy. 2011;3(2):247-267.

16. Mallipeddi R, Rohan LC. Progress in antiretroviral drug delivery using nanotechnology. Int J Nanomedicine. 2010;5:533-547.

17. Kim PS, Read SW. Nanotechnology and HIV: potential applications for treatment and prevention. Wiley Interdiscip Rev Nanomed Nanobiotechnol. 2010;2(6):693-702.

18. Chawla P, Chawla V, Maheshwari R, Saraf SA, Saraf SK. Fullerenes: from carbon to nanomedicine. Mini Rev Med Chem. 2010;10(8): 662-677.

19. Mamo T, Moseman EA, Kolishetti N, et al. Emerging nanotechnology approaches for HIV/AIDS treatment and prevention. Nanomedicine (Lond). 2010;5(2):269-285.

20. Seale-Goldsmith MM, Leary JF. Nanobiosystems. Wiley Interdiscip Rev Nanomed Nanobiotechnol. 2009;1(5):553-567.

21. Hauck TS, Giri S, Gao Y, Chan WC. Nanotechnology diagnostics for infectious diseases prevalent in developing countries. Adv Drug Deliv Rev. 2010;62(4-5):438-448.

22. Wong HL, Chattopadhyay N, Wu XY, Bendayan R. Nanotechnology applications for improved delivery of antiretroviral drugs to the brain. Adv Drug Deliv Rev. 2010;62(4-5):503-517.

23. das Neves J, Amiji MM, Bahia MF, Sarmento B. Nanotechnology-based systems for the treatment and prevention of HIV/AIDS. Adv Drug Deliv Rev. 2010;62(4-5):458-477.

24. Gupta U, Jain NK. Non-polymeric nano-carriers in HIV/AIDS drug delivery and targeting. Adv Drug Deliv Rev. 2010;62(4-5):478-490.

25. Boisselier E, Astruc D. Gold nanoparticles in nanomedicine: preparations, imaging, diagnostics, therapies and toxicity. Chem Soc Rev. 2009;38(6):1759-1782.
26. Nowacek A, Gendelman HE. NanoART, neuroAIDS and CNS drug delivery. Nanomedicine (Lond). 2009;4(5):557-574.

27. Berry CC. Intracellular delivery of nanoparticles via the HIV-1 tat peptide. Nanomedicine (Lond). 2008;3(3):357-365.

28. Peek LJ, Middaugh CR, Berkland C. Nanotechnology in vaccine delivery. Adv Drug Deliv Rev. 2008;60(8):915-928.

29. Vyas TK, Shah L, Amiji MM. Nanoparticulate drug carriers for delivery of HIV/AIDS therapy to viral reservoir sites. Expert Opin Drug Deliv. 2006;3(5):613-628.

30. Guo P. RNA nanotechnology: engineering, assembly and applications in detection, gene delivery and therapy. J Nanosci Nanotechnol. 2005; 5(12):1964-1982.

31. Pedziwiatr-Werbicka E, Ferenc M, Zaborski M, Gabara B, Klajnert B, Bryszewska M. Characterization of complexes formed by polypropylene imine dendrimers and anti-HIV oligonucleotides. Colloids Surf B Biointerfaces. 2011;83(2):360-366.

32. Lee CC, MacKay JA, Fréchet JMJ, Szoka FC. Designing dendrimers for biological applications. Nat Biotechnol. 2005;23:1517-1526.

33. Chrai SS, Murari R, Ahmad I. Liposomes: A review. Pharmaceut Tech. 2002;26:28-34.

34. Kwon GS, Forrest ML. Amphiphilic block copolymer micelles for nanoscale drug delivery. Drug Develop Res. 2006;67:15-22.

35. Croy S, Kwon G. Polymeric micelles for drug delivery. Curr Pharm Des. 2006;12:4669-4684.

36. Zhang J, Li S, Li X. Polymeric nano-assemblies as emerging delivery carriers for therapeutic applications: A review of recent patents. Recent Pat Nanotechnol. 2009;3:225-231.

37. Bekkara-Aounallah F, Gref R, Othman M, et al. Novel PEGylated nanoassemblies nade of self-assembled squalenoyl nucleoside analogues. Adv Funct Mater. 2008;18:3715-3725.

38. Couvreur P, Stella B, Reddy LH, et al. Squalenoyl nanomedicines as potential therapeutics. Nano Lett. 2006;6:2544-2548.

39. Mason TG, Wilking J, Meleson K, Chang C, Graves S. Nanoemulsions: Formation, structure, and physical properties. J Phys Condens Mat. 2006;18:R635-R666.

40. AZoNano. Nanocapsules and dendrimers - Properties and future applications. Available from: http://www.azonano.com/article.aspx? ArticleID=1649. Accessed December 2, 2011.

41. Torchilin VP. Nanoparticulates as Drug Carriers. London, UK: Imperial College Press; 2006; xxix, 724.516.

42. Bawa R. Nanopharmaceuticals: nanopharmaceuticals. Eur J Nanomed. 2010;3:34-40.

43. Fu A, Gu W, Boussert B, et al. Semiconductor quantum rods as single molecule fluorescent biological labels. Nano Lett. 2006;7: 179-182.

44. Liong M, Lu J, Kovochich M, Xia T, et al. Multifunctional inorganic nanoparticles for imaging, targeting, and drug delivery. ACS Nano. 2008;2(5):889-896.

45. Lee JE, Lee N, Kim H, et al. Uniform mesoporous dye-doped silica nanoparticles decorated with multiple magnetite nanocrystals for simultaneous enhanced magnetic resonance imaging, fluorescence imaging, and drug delivery. J Am Chem Soc. 2010;132(2): $552-557$.

46. Law WC, Mahajan SD, Kopwitthaya A, et al. Gene silencing of human neuronal cells for drug addiction therapy using anisotropic nanocrystals. Theranostics. 2012;2(7):695-704

47. Kreuter J. Nanoparticulate systems for brain delivery of drugs. $A d v$ Drug Deliv Rev. 2001;47:65-81.

48. Elsabahy M, Wooley KL. Design of polymeric nanoparticles for biomedical delivery applications. Chem Soc Rev. 2012;41(7): 2545-2561.

49. Liu L, Law WC, Yong KT, et al. Multimodal imaging probes based on Gd-DOTA conjugated quantum dot nanomicelles. Analyst. 2011;136(9): 1881-1886.

50. Ding H, Yong KT, Roy I, et al. Gold nanorods coated with multilayer polyelectrolyte as contrast agents for multimodal imaging. J Phys Chem C. 2007;111:12552. 
51. Dorfs D, Krahne R, Falqui A, Manna L, Giannini C, Zanchet D. In: Andrews DL, Scholas GD, Wiederrecht GP, Comprehensive Nanoscience and Technology. Amsterdam, The Netherlands: Academic Press; 2011:219.

52. Cai W, Shin DW, Chen K, et al. Peptide-labeled near-infrared quantum dots for imaging tumor vasculature in living subjects. Nano Lett. 2006;6:669.

53. Hu R, Yong KT, Roy I, et al. Functionalized near-infrared quantum dots for in vivo tumor vasculature imaging. Nanotechnology. 2010;21(14): 145105.

54. Alam MI, Beg S, Samad A, et al. Strategy for effective brain drug delivery. Eur J Pharm Sci. 2010;40(5):385-403.

55. Mallipeddi R, Rohan LC. Nanoparticle-based vaginal drug delivery systems for HIV prevention. Expert Opin Drug Deliv. 2010;7(1): 37-48.

56. Dou H, Grotepas CB, McMillan JM, et al. Macrophage delivery of nanoformulated antiretroviral drug to the brain in a murine model of neuroAIDS. J Immunol. 2009;183(1):661-669.

57. Nowacek AS, Miller RL, McMillan J, et al. NanoART synthesis, characterization, uptake, release and toxicology for human monocytemacrophage drug delivery. Nanomedicine (Lond). 2009;4(8):903-917.

58. Dash PK, Gendelman HE, Roy U, et al. Long-acting NanoART elicits potent antiretroviral and neuroprotective responses in HIV-1 infected humanized mice. AIDS. July 20, 2012. [Epub ahead of print.]

59. Shaik N, Pan G, Elmquist WF. Interactions of pluronic block copolymers on P-gp efflux activity: experience with HIV-1 protease inhibitors J Pharm Sci. 2008;97(12):5421-5433.

60. Neves JD, Amiji MM, Bahia BF, Sarmento B. Nanotechnology-based systems for the treatment and prevention of HIV/AIDS. Adv Drug Deliv Rev. 2010;62:458-477.

61. Kadiu I, Nowacek A, McMillan J, Gendelman HE. Macrophage endocytic trafficking of antiretroviral nanoparticles. Nanomedicine (Lond). 2011;6(6):975-994.

62. Shegokar R, Singh KK. Surface modified nevirapine nanosuspensions for viral reservoir targeting: In vitro and in vivo evaluation. Int J Pharm. 2011;421(2):341-352.

63. Balkundi S, Nowacek AS, Roy U, Martinez-Skinner A, McMillan J, Gendelman HE. Methods development for blood borne macrophage carriage of nanoformulated antiretroviral drugs. JVis Exp. 2010;(46)pii: 2460 .

64. Gupta U, Jain NK. Non-polymeric nano-carriers in HIV/AIDS drug delivery and targeting..Adv Drug Deliv Rev. 2010;62(4-5):478-490.

65. Mamo T, Moseman EA, Kolishetti N, Salvador-Morales C, et al. Emerging nanotechnology approaches for HIV/AIDS treatment and prevention. Nanomedicine (Lond). 2010;5(2):269-285.

66. Borgmann K, Rao KS, Labhasetwar V, Ghorpade A. Efficacy of Tat-conjugated ritonavir-loaded nanoparticles in reducing HIV-1 replication in monocyte-derived macrophages and cytocompatibility with macrophages and human neurons. AIDS Res Hum Retroviruses. 2011;27(8):853-862.

67. Destache CJ, Belgum T, Goede M, Shibata A, Belshan MA. Antiretroviral release from poly (DL-lactide-co-glycolide) nanoparticles in mice. J Antimicrob Chemother. 2010;65(10):2183-2187.

68. Saiyed ZM, Gandhi NH, Nair MP. Magnetic nanoformulation of azidothymidine $5^{\prime}$-triphosphate for targeted delivery across the blood-brain barrier. Int J Nanomedicine. 7, 2010;5:157-166.

69. Ramana LN, Sethuraman S, Ranga U, Krishnan UM. Development of a liposomal nanodelivery system for nevirapine. J Biomed Sci. 2010; 17:57.

70. Cheng Y, Li D, Ji B, Shi X, Gao H. Structure-based design of carbon nanotubes as HIV-1 protease inhibitors:atomistic and coarse-grained simulations. J Mol Graph Model. 2010;29(2):171-177.

71. Mahajan SD, Law WC, Aalinkeel R, et al. Nanoparticle-mediated targeted delivery of antiretrovirals to the brain. Methods Enzymol. 2012;509:43-64.

72. Michalet X, Pinaud FF, Bentolila LA, et al. Quantum dots for live cells, in vivo imaging, and diagnostics. Science. 2005;307:538-544.

73. Prasad PN. Introduction in Biophotonics. New York, NY: Wiley; 2003.

74. Prasad PN. Nanophotonics. New York, NY: Wiley; 2004.
75. Mahajan SD, Roy I, Xu G, et al. Enhancing the delivery of anti retroviral drug "Saquinavir" across the blood brain barrier using nanoparticles. Curr HIV Res. 2010;8(5):396-404.

76. Mahajan SD, Reynolds JL, Aalinkeel R, et al. Enhancing the transversing efficiency and efficacy of the anti retroviral drug "saquinavir" using nanotechnology: Implications for nanotherapeutics in neuro-AIDS. HIV Persistance during Therapy. Fourth International Workshop. December 2009. Global Antiviral Journal. 2009;5(2):45-46.

77. Xu L, Liu Y, Chen Z, et al. Surface-engineered gold nanorods: Promising DNA vaccine adjuvant for HIV-1 treatment. Nano Lett. February 28, 2012. [Epub ahead of print.]

78. Kalkanidis M, Pietersz GA, Xiang SD, et al. Methods for nano-particle based vaccine formulation and evaluation of their immunogenicity. Methods. 2006;40(1):20-29.

79. Wang X, Uto T, Akagi T, Akashi M, Baba M. Poly(gamma-glutamic acid) nanoparticles as an efficient antigen delivery and adjuvant system: potential for an AIDS vaccine. J Med Virol. 2008;80(1): 11-19.

80. Tang S, Hewlett I. Nanoparticle-based immunoassays for sensitive and early detection of HIV-1 capsid (p24) antigen. J Infect Dis. 2010; 201(Supp1 1):S59-S64.

81. Lee KB, Kim E-Y, Mirkin CA, Wolinsky SM. The use of nanoarrays for highly sensitive and selective detection of human immunodeficiency virus type 1 in plasma. Nano Lett. 2004;4(10):1869-1872.

82. de Fougerolles A, Vornlocher HP, Maraganore J, Lieberman J. Interfering with disease: a progress report on siRNA-based therapeutics. Nat Rev Drug Discov. 2007;6(6):443-453.

83. Aigner A. Delivery systems for the direct application of siRNAs to induce RNA interference (RNAi) in vivo. J Biomed Biotechnol. 2006(4): 71659.

84. Higuchi Y, Kawakami S, Hashida M. Strategies for in vivo delivery of siRNAs: recent progress. Bio Drugs. 2010;24(3):195-205.

85. Raviña M, Paolicelli P, Seijo B, Sanchez A. Knocking down gene expression with dendritic vectors. Mini Rev Med Chem. 2010;10(1): 73-86.

86. Buxton DB. Nanomedicine for the management of lung and blood diseases. Nanomedicine (Lond). 2009;4(3):331-339.

87. de Martimprey H, Vauthier C, Malvy C, Couvreur P. Polymer nanocarriers for the delivery of small fragments of nucleic acids: oligonucleotides and siRNA. Eur J Pharm Biopharm. 2009;71(3):490-504.

88. de Fougerolles AR. Delivery vehicles for small interfering RNA in vivo. Hum Gene Ther. 2008;19(2):125-132.

89. Toub N, Malvy C, Fattal E, Couvreur P. Innovative nanotechnologies for the delivery of oligonucleotides and siRNA. Biomed Pharmacother. 2006;60(9):607-620.

90. Bonoiu AC, Mahajan SD, Ding H, et al. Nanotechnology approach for drug addiction therapy: gene silencing using delivery of gold nanorodsiRNA nanoplex in dopaminergic neurons. Proc Natl Acad Sci U S A. 2009;106(14):5546-5550.

91. Zhou J, Neff CP, Liu X, et al. Systemic administration of combinatorial dsiRNAs via nanoparticles efficiently suppresses HIV-1 infection in humanized mice. Mol Ther. 2011;19(12):2228-2238.

92. Zhou J, Shu Y, Guo P, Smith DD, Rossi JJ. Dual functional RNA nanoparticles containing phi29 motor pRNA and anti-gp120 aptamer for cell-type specific delivery and HIV-1 inhibition. Methods. 2011;54(2): 284-294.

93. Mahajan SD, Aalinkeel R, Reynolds JL, et al. Nanotherapeutics using an HIV-1 poly A and transactivator of the HIV-1 LTR-(TAR-) specific siRNA. Patholog Res Int. 2011;2011:719139.

94. Jiménez JL, Clemente MI, Weber ND, et al. Carbosilane dendrimers to transfect human astrocytes with small interfering RNA targeting human immunodeficiency virus. Bio Drugs. 2010;24(5):331-343.

95. Gonzalo T, Clemente MI, Chonco L, et al. Gene therapy in HIV-infected cells to decrease viral impact by using an alternative delivery method. Chem Med Chem. 2010;5(6):921-929.

96. Bonoiu A, Mahajan SD, Ye L, et al. MMP-9 gene silencing by a quantum dot-siRNA nanoplex delivery to maintain the integrity of the blood brain barrier. Brain Res. 2009;1282:142-155. 
97. Kim SS, Subramanya S, Peer D, Shimaoka M, Shankar P. Antibodymediated delivery of siRNAs for anti-HIV therapy. Methods Mol Biol. 2011;721:339-353.

98. Letvin NL. Progress toward an HIV vaccine. Annu Rev Med. 2005; 56:213-223.

99. Mallipeddi R, Rohan LC. Progress in antiretroviral drug delivery using nanotechnology. Int J Nanomedicine. 2010;5:533-547.

100. Kuo YC, Lee CL. Methylmethacrylate-sulfopropylmethacrylate nanoparticles with surface RMP-7 for targeting delivery of antiretroviral drugs across the blood-brain barrier. Colloids Surf B Biointerfaces. 2012;90:75-82.

101. das Neves J, Michiels J, Ariën KK, et al. Polymeric nanoparticles affect the intracellular delivery, antiretroviral activity and cytotoxicity of the microbicide drug candidate dapivirine. Pharm Res. 2012;29(6): 1468-1484.

102. Kuo YC, Chung CY. Solid lipid nanoparticles comprising internal Compritol 888 ATO, tripalmitin and cacao butter for encapsulating and releasing stavudine, delavirdine and saquinavir. Colloids Surf B Biointerfaces. 2011;88(2):682-690.

103. Kuo YC, Yu HW. Polyethyleneimine/poly-( $\gamma$-glutamic acid)/poly (lactide-co-glycolide) nanoparticles for loading and releasing antiretroviral drug. Colloids Surf B Biointerfaces. 2011;88(1):158-164.
104. Yang L, Chen L, Zeng R, et al. Synthesis, nanosizing and in vitro drug release of a novel anti-HIV polymeric prodrug: chitosan-Oisopropyl-5'-O-d4T monophosphate conjugate. Bioorg Med Chem. 2010;18(1):117-123.

105. Destache CJ, Belgum T, Christensen K, Shibata A, Sharma A, Dash A. Combination antiretroviral drugs in PLGA nanoparticle for HIV-1. BMC Infect Dis. 2009;9:198.

106. Baert L, van't Klooster G, Dries W, et al. Development of a long-acting injectable formulation with nanoparticles of rilpivirine (TMC278) for HIV treatment. Eur J Pharm Biopharm. 2009;72(3):502-508.

107. Wan L, Zhang X, Pooyan S, et al. Optimizing size and copy number for PEG-FMLF (n-formyl-methionyl-leucyl-phenylalanine) nanocarrier uptake by macrophages. Bioconjug Chem. 2008;19(1):28-38.

108. Kaur CD, Nahar M, Jain NK. Lymphatic targeting of zidovudine using surfaceengineered liposomes. J Drug Target. 2008;16(10):798-805.

109. Dou H, Morehead J, Destache CJ, et al. Laboratory investigations for the morphologic, pharmacokinetic, and anti-retroviral properties of indinavir nanoparticles in human monocyte-derived macrophages. Virology. 2007;358(1):148-158.
International Journal of Nanomedicine

\section{Publish your work in this journal}

The International Journal of Nanomedicine is an international, peerreviewed journal focusing on the application of nanotechnology in diagnostics, therapeutics, and drug delivery systems throughout the biomedical field. This journal is indexed on PubMed Central, MedLine, CAS, SciSearch $\AA$, Current Contents ${ }^{\circledR} /$ Clinical Medicine,

\section{Dovepress}

Journal Citation Reports/Science Edition, EMBase, Scopus and the Elsevier Bibliographic databases. The manuscript management system is completely online and includes a very quick and fair peer-review system, which is all easy to use. Visit http://www.dovepress.com/ testimonials.php to read real quotes from published authors. 